\title{
HUBUNGAN PENGETAHUAN WANITA USIA SUBUR TERHADAP PEMILIHAN ALAT KONTRASEPSI IUD DI RB MARIANA KECAMATAN SUNGAI RAYA KABUPATEN KUBU RAYA TAHUN 2018
}

\author{
Katarina Iit ${ }^{1}$, Megalina Limoy ${ }^{2}$
}

\author{
Akademi Kebidanan Panca Bhakti \\ Email korespondensi: katarinaiit17@gmail.com
}

\begin{abstract}
Abstrak
Pemilihan alat kontrasepsi Intra Uterine Device (IUD) oleh wanita usia subur antara lain di pengaruhi oleh pengetahuan. Dari studi pendahuluan yang di lakukan pada 10 akseptor tidak menggunakan Intra Uterine Device (IUD) di dapatkan bahwa 3 orang akseptor tidak mengetahui tentang kontrasepsi Intra Uterine Device (IUD), 4 orang akseptor takut menggunakan Intra Uterine Device (IUD) dan 3 orang akseptor tidak mendapatkan izin dari suami. Tujuan penelitian ini adalah diperolehnya informasi tentang hubungan pengetahuan ibu terhadap pemilihan alat kontrasepsi IUD, meliputi umur, paritas, pendidikan, pekerjaan an dukungan suami. Metode yang digunakan dalam penelitian ini adalah menggunakan rancangan penelitian Cross Sectional, adapun jumlah responden berdasarkan estimasi sebesar 107 orang ibu akseptor KB. Penggumpulan data menggunakan kuesioner. Analisa data dilakukan dengan analisa univariat (distribusi frekuensi) dan analisa bivariat dengan uji kai kuadrat. Hasil analisa univariat, sebagian inbu pengetahuannya kurang terhadap alat kontrasepsi IUD (45,8\%), berumur $\geq 20$ tahun $(84,1 \%)$, paritas $\geq 2(37,4 \%)$, pendidikan tinggi $(47,7 \%)$, pekerjaan yang bekerja $(67,3 \%)$, dukungan suami yang mendukung $(49,5 \%)$. Hasil analisa bivariat, variabel yang mempunyai hubungan bermakna dengan pengetahuan ibu terhadap alat kontrasepsi IUD adalah umur $(\mathrm{p}=0,016$ dan $\mathrm{OR}=4,879)$, paritas $(\mathrm{p}=0,001$ dan $\mathrm{OR}=0,239)$, pendidikan ( $\mathrm{p}=0,012$ dan $\mathrm{OR}=0,359)$ dan dukungan suami ( $\mathrm{p}=0,012$ dan $\mathrm{OR}=2,818)$, sedangakan yang tidak mempnyai hubungan signifikan dengan pengetahuan terhadap alat kontrasepsi IUD adalah pekerjaan $(\mathrm{p}=1,000$ dan $\mathrm{OR}=1,005)$. Saran dalam penelitian ini adalah dapat meningkatkan pemahaman masyarakat khususnya pasangan usia subur (PUS) tentang alat kontrasepsi IUD, koordinasi bersama PLKB, bidan desa, dan kader kesehatan serta tokoh masyarakat untuk mensosialisasikan alat kontrasepsi IUD.
\end{abstract}

Kata Kunci: Faktor-Faktor, Mempengaruhi, Pemilihan, IUD, Wanita Usia Subur

\section{Pendahuluan}

Keluarga Berencana menurut World Health Organization (WHO) (1970) adalah tindakan yang membantu individu atau pasangan suami istri untuk mendapatkan objektif-objektif tertentu, menghindarkan kelahiran yang tidak diinginkan, mendapatkan kelahiran yang memang diinginkan, mengatur interval diantara kelahiran, mengontrol waktu saat kelahiran dalam hubungan dengan umur suami istri, dan menentukan jumlah anak dalam keluarga (Marmi, 2015).

Program Keluarga Berencana (KB) adalah suatu langkah-langkah atau suatu usaha

\footnotetext{
${ }^{1}$ Dosen Akademi Kebidanan Panca Bhakti Pontianak

${ }^{2}$ Dosen Akademi Kebidanan Panca Bhakti Pontianak
}

kegiatan yang disusun oleh organisasiorganisasi Keluarga Berencana (KB) dan merupakan program pemerintah untuk mencapai rakyat yang sejahtera berdasarkan peraturan dan perundang-undangan kesehatan (Marmi, 2015).

Pemakaian kontrasepsi diantara metode Keluarga Berencana (KB) modern yang paling banyak digunakan oleh Pasangan Usia Subur berstatus kawin adalah metode suntikan 32\% dan pil $14 \%$. Peningkatan pemakaian suntik keluarga Berencana $(\mathrm{KB})$ diiringi oleh turunnya peserta Intra Uterine Device (IUD). Pemakaian Intra Uterine Device (IUD) mengalami 
penurunan selama 20 tahun, dari 13\% tahun 1991 menjadi 4\% tahun 2012, sebaliknya peserta Keluarga Berencana (KB) suntik mengalami peningkatan dari 12\% tahun 1991 menjadi 32\% tahun 2012 (SDKI, 2012). Intra Uterine Device (IUD) atau Alat Kontraspsi Dalam Rahim adalah alat kontrasepsi yang dimasukkan ke dalam rongga rahim, terbuat dari plastik fleksibel (Irianto, 2014).

Menurut BKKBN Kalimantan Barat tahun (2016) data peserta Keluarga Berencana (KB) Aktif di Provinsi Kalimantan Barat tahun 2016 didapatkan penggunaaan jenis kontrasepsi suntik merupakan alat kontrasepsi yang paling banyak di pilih akseptor di banding alat kontrasepsi yang lainnya dengan persentase $(44,83)$ dan yang paling sedikit di pilih akseptor yaitu MOP dengan persentase $(0,74)$.

Berdasarkan Undang-Undang No.52/Tahun 2009 tentang Perkembangan Kependudukkan dan pembangunan keluarga mengamanatkan keluarga berencana sebagai upaya mengatur kelahiran anak, jarak, dan usia ideal melahirkan, mengatur kehamilan, melalui promosi, perlindungan dan bantuan sesuai dengan hak reproduksi untuk mewujudkan keluarga yang berkualitas (Bakar, 2014).

Upaya-upaya yang di lakukan antara lain yaitu Upaya Pelayanan Kesehatan keluarga yang meliputi Pelayanan kesehatan ibu hamil, pelayanan imunisasi Tetanus Toksoid (TT) bagi wanita Usia Subur dan Ibu Hamil, pelayanan kesehatan ibu bersalin, pelayanan kesehatan ibu nifas, pelayanan / penanganan komplikasi kebidanan, pelayanan kesehatan Neonatal, pelayanan komplikasi neonatal, pelayanan imunisasi, pelayanan kesehatan anak usia sekolah, pelayanan kesehatan pada kasus kekerasan terhadap anak (KTA), pelayanan kesehatan peduli Remaja (PKPR) dan pelayanan Kontrasepsi (Dinkes Kubu Raya, 2016).

Berdasarkan studi pendahuluan yang dilakukan oleh peneliti di RB Mariana di ketahui bahwa bidan yang sudah melakukan pelatihan $C T U$ ada 1 orang Bidan. Hasil wawancara langsung dari 10 orang akseptor yang tidak menggunakan Intra Uterine Device (IUD) mengatakan bahwa 3 orang akseptor tidak mengetahui tentang kontrasepsi Intra Uterine Device (IUD), 4 orang akseptor takut menggunakan Intra Uterine Device (IUD) dan 3 orang akseptor tidak mendapatkan izin dari suami.

\section{Metode}

Desain penelitian deskriptif menggunakan pendekatan Cross Sectional. Dalam penelitian ini jumlah sampelnya sebanyak 107 orang, teknik sampling yang di gunakan yaitu Sampling Aksidental.

\section{Hasil dan Pembahasan}

Tabel 1. Hubungan Antara Umur dengan Pengetahuan responden tentang Kontrasepsi AKDR/IUD di Rumah Bersalin Mariana

\begin{tabular}{|c|c|c|c|c|c|}
\hline \multirow{3}{*}{ Umur } & $\begin{array}{r}\text { Pengeta } \\
\text { kontrasep }\end{array}$ & $\begin{array}{l}\text { tentang } \\
\text { DR/IUD }\end{array}$ & \multirow{2}{*}{ Total } & \multirow{3}{*}{ OR $(95 \% \mathrm{CI})$} & \multirow{3}{*}{ P Value } \\
\hline & Tinggi & Rendah & & & \\
\hline & $\mathrm{N} \quad \%$ & $\mathrm{~N} \quad \%$ & $\mathrm{~N}$ & & \\
\hline
\end{tabular}




\begin{tabular}{ccccccccc}
\hline$>20$ & 46 & 51,1 & 44 & 48,9 & 90 & 100 & 4,879 & 0,016 \\
$<20$ & 3 & 17,6 & 14 & 82,4 & 17 & 100 & $(1,3-18,1)$ & \\
Jumlah & 49 & 45,8 & 58 & 54,2 & 107 & 100 & & \\
\hline
\end{tabular}

Hubungan anatara umur dengan pengetahuan responden tentang kontrasepsi AKDR (IUD), dalam penelitian ini yaitu responden yang berusia > 20 tahun yang pengetahuan tentang kontrasepsi AKDR (IUD) tinggi ada $51,1 \%$, sedangkan responden yang berusia $<20$ tahun yng pengetahuan tentang kontrasepsi AKDR (IUD) tinggi ada 17,6\%.

Hasil uji statistik nilai $\mathrm{P}$ value $=0,016$ dengan demikian $\mathrm{P}$ value sama dengan nilai Alpha $(0,005)$, sehingga hal ini berarti ada hubungan yang bermakna antara umur dengan pengetahuan responden kontrasepsi AKDR/ IUD. Sedangkan nilai OR 4,879 berarti responden mempunyai kemungkinan pengetahuan tentang kontrasepsi AKDR (IUD) 1 kali dibandingkan dengan responden yang umurnya $<20$ tahun.

Tabel 2 Hubungan Antara Paritas dengan Pengetahuan responden tentang Kontrasepsi AKDR/IUD

\begin{tabular}{|c|c|c|c|c|c|c|c|c|}
\hline \multirow{3}{*}{ Paritas } & \multicolumn{4}{|c|}{$\begin{array}{c}\text { Pengetahuan tentang } \\
\text { kontrasepsi AKDR/IUD }\end{array}$} & \multirow{2}{*}{\multicolumn{2}{|c|}{ Total }} & \multirow[t]{3}{*}{ OR (95\%CI) } & \multirow[t]{2}{*}{ P Value } \\
\hline & \multicolumn{2}{|c|}{ Tinggi } & \multicolumn{2}{|c|}{ Rendah } & & & & \\
\hline & $\mathrm{N}$ & $\%$ & $\mathrm{n}$ & $\%$ & $\mathrm{~N}$ & $\%$ & & \\
\hline$>2$ & 10 & 25,0 & 30 & 75,0 & 40 & 100 & 0,239 & \\
\hline$<2$ & 39 & 58,2 & 28 & 41,8 & 67 & 100 & $(0,10-0,56)$ & 0,001 \\
\hline
\end{tabular}

Hubungan anatara paritas dengan pengetahuan responden tentang kontrasepsi AKDR (IUD), dalam penelitian ini yaitu responden yang paritasnya $>2$ yang pengetahuan tentang kontrasepsi AKDR (IUD) tinggi ada $25,0 \%$, sedangkan responden yang paritasnya $<2$ yang pengetahuan tentang kontrasepsi AKDR (IUD) tinggi ada 58,2\%.

Hasil uji statistik nilai $\mathrm{P}$ value $=0,001$ dengan demikian $\mathrm{P}$ value lebih kecil dari nilai Alpha $(0,005)$, sehingga hal ini berarti ada hubungan yang bermakna antara paritas dengan pengetahuan responden kontrasepsi AKDR/ IUD. Sedangkan nilai OR 0,239 berarti responden mempunyai kemungkinan pengetahuan tentang kontrasepsi AKDR (IUD) 0,10 kali dibandingkan dengan responden yang paritasnya $<2$.

Table 3 Hubungan Antara Pendidikan dengan Pengetahuan responden tentang Kontrasepsi AKDR/IUD

\begin{tabular}{|c|c|c|c|c|c|c|c|c|}
\hline \multirow{3}{*}{ Pendidikan } & \multicolumn{4}{|c|}{$\begin{array}{l}\text { Pengetahuan tentang } \\
\text { kontrasepsi AKDR/IUD }\end{array}$} & \multirow{2}{*}{\multicolumn{2}{|c|}{ Total }} & \multirow[t]{3}{*}{ OR $(95 \% \mathrm{CI})$} & \multirow[t]{2}{*}{ P Value } \\
\hline & \multicolumn{2}{|c|}{ Tinggi } & \multicolumn{2}{|c|}{ Rendah } & & & & \\
\hline & $\mathrm{N}$ & $\%$ & $\mathrm{n}$ & $\%$ & $\mathrm{~N}$ & $\%$ & & \\
\hline SD - SMP & 19 & 33,9 & 37 & 66,1 & 56 & 100 & 0,359 & \\
\hline SMA-PT & 30 & 58,8 & 21 & 41,2 & 51 & 100 & $(0,16-0,78)$ & 0,012 \\
\hline Jumlah & 49 & 45,8 & 58 & 54,2 & 107 & 100 & & \\
\hline
\end{tabular}

Hubungan anatara pendidikan dengan pengetahuan responden tentang kontrasepsi
AKDR (IUD), dalam penelitian ini yaitu responden yang pendidikannya SD-SMP yang 
pengetahuan tentang kontrasepsi AKDR (IUD) tinggi ada $(33,9 \%)$, sedangkan responden yang pendidikannya SMA-PT yang pengetahuan tentang kontrasepsi AKDR (IUD) tinggi ada $(58,8 \%)$.

Hasil uji statistik nilai $\mathrm{P}$ value $=0,012$ dengan demikian $\mathrm{P}$ value lebih kecil dari nilai Alpha (0,005), sehingga hal ini berarti ada hubungan yang bermakna antara pendidikan dengan pengetahuan responden kontrasepsi AKDR/ IUD. Sedangkan nilai OR 0,359 berarti responden mempunyai kemungkinan pengetahuan tentang kontrasepsi AKDR (IUD) 0,16 kali dibandingkan dengan responden yang berpendidikan SMA-PT

Tabel 4 Hubungan Antara Pekerjaan dengan Pengetahuan responden tentang Kontrasepsi AKDR/IUD

\begin{tabular}{|c|c|c|c|c|c|c|c|c|}
\hline \multirow{3}{*}{ Pekerjaan } & \multicolumn{4}{|c|}{$\begin{array}{l}\text { Pengetahuan tentang } \\
\text { kontrasepsi AKDR/IUD }\end{array}$} & \multirow{2}{*}{\multicolumn{2}{|c|}{ Total }} & \multirow[t]{3}{*}{ OR $(95 \% \mathrm{CI})$} & \multirow[t]{2}{*}{ P Value } \\
\hline & \multicolumn{2}{|c|}{ Tinggi } & \multicolumn{2}{|c|}{ Rendah } & & & & \\
\hline & $\mathrm{N}$ & $\%$ & $\mathrm{~N}$ & $\%$ & $\mathrm{~N}$ & $\%$ & & \\
\hline Bekerja & 33 & 45,8 & 39 & 54,2 & 72 & 100 & & \\
\hline $\begin{array}{c}\text { Tidak } \\
\text { bekerja }\end{array}$ & 16 & 45,7 & 19 & 54,3 & 35 & 100 & $\begin{array}{c}1,005 \\
(0,44-2,26)\end{array}$ & 1,000 \\
\hline Jumlah & 49 & 45,8 & 58 & 54,2 & 107 & 100 & & \\
\hline
\end{tabular}

Hasil penelitian hubungan anatara pekerjaan dengan pengetahuan responden tentang kontrasepsi AKDR (IUD), dalam penelitian ini yaitu responden pekerjaan yang bekerja yang pengetahuan tentang kontrasepsi AKDR (IUD) tinggi ada (45,8\%), sedangkan responden yang tidak bekerja yang pengetahuan tentang kontrasepsi AKDR (IUD) tinggi ada
$(45,7 \%)$.

Hasil uji statistik diperoleh nilai $\mathrm{P}$ value $=1,000$ dengan demikian $\mathrm{P}$ value lebih besar dari nilai Alpha (0,005), sehingga tidak ada hubungan antrara pekerjaan dengan pengetahuan responden tentang kontrasepsi AKDR (IUD).

Tabel 5. Hubungan Antara Dukungan Suami dengan Pengetahuan responden tentang Kontrasepsi AKDR/IUD

\begin{tabular}{|c|c|c|c|c|c|c|c|c|}
\hline \multirow{3}{*}{$\begin{array}{l}\text { Dukungan } \\
\text { suami }\end{array}$} & \multicolumn{4}{|c|}{$\begin{array}{c}\text { Pengetahuan tentang } \\
\text { kontrasepsi AKDR/IUD }\end{array}$} & \multirow{2}{*}{\multicolumn{2}{|c|}{ Total }} & \multirow[t]{3}{*}{ OR $(95 \% \mathrm{CI})$} & \multirow[t]{2}{*}{ P Value } \\
\hline & \multicolumn{2}{|c|}{ Tinggi } & \multicolumn{2}{|c|}{ Rendah } & & & & \\
\hline & $\mathrm{N}$ & $\%$ & $\mathrm{~N}$ & $\%$ & $\mathrm{~N}$ & $\%$ & & \\
\hline Mendukung & 31 & 58,5 & 22 & 41,5 & 53 & 100 & 2,818 & \\
\hline $\begin{array}{l}\text { Tidak } \\
\text { mendukung }\end{array}$ & 18 & 33,3 & 36 & 66,7 & 54 & 100 & $(1,28-6,18)$ & 0,012 \\
\hline Jumlah & 49 & 45,8 & 58 & 54,2 & 107 & 100 & & \\
\hline
\end{tabular}

Hubungan antara dukungan suami dengan pengetahuan responden tentang kontrasepsi AKDR (IUD), dalam penelitian ini yaitu responden yang dukungan suami yang pengetahuan tentang kontrasepsi AKDR (IUD) tinggi ada (58,5\%), sedangkan responden yang dukungan suami tidak mendukung yang pengetahuan tentang kontrasepsi AKDR (IUD) 
tinggi ada $(33,3 \%)$.

Hasil uji statistik nilai $\mathrm{P}$ value $=0,012$ dengan demikian $\mathrm{P}$ value lebih kecil dari nilai Alpha (0,005), sehingga hal ini berarti ada hubungan yang bermakna antara dukungan suami dengan pengetahuan responden kontrasepsi AKDR/ IUD. Sedangkan nilai OR 2,818 berarti responden mempunyai kemungkinan pengetahuan tentang kontrasepsi AKDR (IUD) 1 kali dibandingkan dengan responden yang ukungan suaminya tidak mendukung.

Hasil penelitian mengenai pengetahuan ibu tentang Kontrasepsi IUD yaitu ibu dengan pengetahuan rendah ada 58 responden $(54,2 \%)$. Penelitian ini sesuai dengan pendapat (Notoatmodjo,2007) Pengetahuan adalah merupakan hasil dari tau dan ini setelah orang melakukan penginderaan terhadap obyek tertentu. Penginderaan terjadi melalui panca indra manusia, yakni indra pengeliatan, pendengaran, penciuman, rasa dan telinga Pengetahuan adalah merupakan hasil dari tau dan ini setelah orang melakukan penginderaan terhadap obyek tertentu. Penginderaan terjadi melalui panca indra manusia, yakni indra pengeliatan, pendengaran, penciuman, rasa dan telinga.

Menurut pendapat peneliti dapat dilihat pengetahuan sangat berperan dan berpengaruh dalam pencapaian pemilihan dan penggunaan alat kontrasepsi IUD. Pengetahuan dapat dipengaruhi dari sumber informasi, media cetak, media elektronik internet dan tenaga kesehatan. Berdasarkan umur sebagian responden berada pada kelompok umur $\geq 20$ tahun sebanyak 46 responden $(51,1 \%)$. Hasil uji statistik diperoleh nili $\mathrm{P}$ value 0,016 berarti ada hubungan antara umur dengan pengetahuan respondeen tentang kontrasepsi AKDR (IUD).

Hasil penelitian ini sesuai dengan pendapat (Notoatmodjo,2003) umur adalah lamanya hidup seseorang dari sejak lahir yang dinyatakan dengan tahun. Telah lama diketahui bahwa umur sangat berpengaruh terhadap proses reproduksi. Umur yang menganggap optimal untuk menentukan suatu keputusan bagi dirinya dan lingkungannya. Dengan bertambahnya umur, maka bertambahnya pengetahuan ibu yang didapat dari televisi, radio, majalah dan nakes.

Menurut teori, umur ibu yang masih muda perkembangan organ-organ reproduksi dan fungsi fisiologis belum optimal serta belum tercapai emosi kejiwaan yang cukup matang sehingga akan mempengaruhi terhadap fungsi fisiologis. Dengan bertambahnya usia semakin dewasa maka fungsi fisiologisnya bisa semakin optimal, pola pemikiran semakin bertambah, pengetahuannya semakin luas (Soetiningsih, 2003).

Menurut analisa peneliti dari hasil penelitian menunjukkan bahwa pada umur $\geq 20$ tahun memilki pengetahuan yang baik, hal ini dikarenakan pada golongan umur $\geq 20$ tahun perkembangan otaknya sudah mulai optimal untuk menentukan suatu keputusan yang baik bagi dirinya dan lingkungannya serta dapat berfikiran lebih dewasa. Umur $\geq 20$ tahun pada umumnya memiliki semangat belajar dan rasa ingin tahu yang tinggi serta memiliki daya ingat yang kuat sehingga dapat memiliki pengetahuan dan wawasan yang luas.

Hasil penelitian mengenai pengetahuan ibu 
tentang Kontrasepsi IUD menurut paritas responden yaitu $<2$ sebanyak 39 responden $(58,2 \%)$. Hasil uji statistik diproleh nilai P value 0,001 . Berarti ada hubungan antara paritas dengan pengetahuan responden tentang kontraepsi AKDR (IUD). Penelitian ini sesuai dengan pendapat (Manuaba, 2010). Jumlah anak yang dilahirkan oleh seorang wanita dalam masa reproduksi merupakan reproduksi yang optimal. Interval kehamilan $>2$ tahun dengan jumlah kehamilan atau kelahiran 2-3 orang dan menghindari abortus ilegal. Seorang wanita dikatakan berparitas rendah apabila $<2$ orang yang paling aman jika ditinjau dari kematian maternal. Menurut pendapat peneliti bahwa sebagian besar responden terdapat pada multigravida yaitu ibu yang mempunyai anak $>1$ karena ibu sudah memiliki pengalaman dan pengetahuan dalam menggunakan KB IUD.

Hasil penelitian mengenai pengetahuan ibu tentang Kontrasepsi IUD berdasarkan tingkat pendidikan yang tinggi (SMA-PT) sebesar 30 responden $(58,8 \%)$. Hasil uji statistik diperoleh nilai $\mathrm{P}$ value $=0,012$ berarti ada hubungan antara pendidikan dengan pengetahuan responden tentang kontrasepsi AKDR (IUD).

Menurut teori, perubahan perilaku kesehatan melalui cara pendidikan ini diawali dengan cara pemberian informasi-informasi kesehatan. Selanjutnya dengan pengetahuanpengetahuan itu akan menimbulkan kesadaran mereka, dan akhirnya akan menyebabkan orang berprilaku sesuai dengan pengetahuan yang dimilikinya (Notoatmodjo, 2010). Semakin tinggi tingkat pendidikan seseorang maka diharapkan akan meningkatkan kemampuan mengembangkan potensi diri, perubahan sikap dan tata laku sehingga meningkatkan kemampuan proses pikir dalam masyarakat, memiliki kemampuan memilih untuk bertindak yang berdasarkan ilmu pengetahuan (Roslina, 2004).

Menurut analisa peneliti tingkat pendidikan golongan SMA-PT sangat berpengaruh terhadap pemahaman seseorang. Dimana semakin tinggi tingkat pendidikan seseorang, maka seseorang tersebut dapat menerima dengan mudah informasi yang diberikan dan semakin baik tingkat pengetahuannya.

Hasil penelitian mengenai pengetahuan ibu tentang Kontrasepsi IUD menurut pekerjaan responden yaitu ibu yang bekerja sebesar 33 responden $(45,8 \%)$. Hasil uji statistik diproleh nilai $\mathrm{P}$ value 1,000 yang pengetahuan tentang kontrasepsi AKDR (IUD). Berarti tidak ada hubungan antara pekerjaan dengan pengetahuan responden tentang kontraepsi AKDR (IUD). Pekerjaan merupakan suatu kegiatan atau aktivitas seseorang untuk memperoleh penghasilan guna memenuhi kebutuhan hidup sehari-hari (Notoatmodjo, 2003).

Menurut peneliti hal ini sesuai karena pekerjaan dengan pengetahuan seseorang berkembang dan berubah bahkan seringkali tidak disadari oleh pelakunya. Seseorang bekerja karena ada sesuatu yang hendak dicapainya dan orang berharap bahwa aktivitas kerja yang dilakukannya akan membawanya kepada sesuatu keadaan yang lebih memuaskan dari pada keadaan sebelumnya. Pekerjaan juga dapat berpengaruh terhadap pemilihan kontrasepsi.

Green (1980) menggemukakan bahwa 
suami merupakan kelompok referensi penting dalam membantu pembentukan perilaku dalam diri seseorang. Adanya dukungan suami untuk menganjurkan ibu agar mengunakan kontrasepsi IUD/AKDR dapat meningkatkan cakupan akseptor kontrasepsi IUD/AKDR.

Responden yang mendapatkan dukungan $\begin{array}{llll}\text { suami } & \text { ada } & 31 & \text { orang }\end{array}$ $(58,5 \%)$ yang pengetahuan tentang kontrasepsi AKDR (IUD) lebih besar jumlahnya dibandingkan dengan responden yang tidak mendapatkan dukungan suami. Hasil uji statistik diperoleh nilai $\mathrm{P}$ value $=0,012$ dan nilai OR 2,818. berarti ada hubungan antara dukungan suami dengan pengetahuan responden tentang kontrasepsi AKDR (IUD).

Peneliti beranggapan bahwa dalam pemanfaatan alat kontrasepsi IUD seorng ibu harus terlebih dahulu melakukan musyawaroh dengan suamiinya, sehingga apa yang dilakukan menjadi kesepakatan bersama. Selain itu harus dapat dipahami bahwa program keluarga bukan hanya mutlak dilakukan oleh seorang istri, namun lebih jauh dari itu harus dilakukan pula oleh suami. Sebelum istri memakai alat kontrasepsi pada umumnya mengadakan musyawarah terlebih dahulu (kesepakatan suami/istri meminta prsetujuan suami).

\section{Kesimpulan}

Hasil penelitian yang dilakukan di di RB Mariana Kecamatan Sungai Raya Kabupaten Kubu Raya Tahun 2018 hasilnya adalah pengetahun ibu tentang kontrasepsi IUD masih rendah $(54,2 \%)$. Hubungan antara pengetahuan ibu dalam memilih alat kontrasepsi AKDR/IUD pada tanu 2018, diperoleh setelah dilakukan uji statistik didapat variabel yang berhubungan yaitu faktor umur $(\mathrm{P}$ value $=0,016)$, paritas $(\mathrm{P}$ value $=0,001)$ pendidikan $(\mathrm{P}$ value $=0,012)$ dan dukungan suami $(P$ value $=0,012)$.

Sedangkan yang tidak berhubungan antara pekerjaan dengan pengetahuan responden tentang kontrasepsi AKDR/IUD di RB Mariana Kecamatan Sungai Raya Kabupaten Kubu Raya Tahun 2018 nilai $(\mathrm{P}$ value $=1,000)$. Saran dalam penelitian ini adalah dapat meningkatkan pemahaman masyarakat khususnya pasangan usia subur (PUS) tentang alat kontrasepsi IUD, koordinasi bersama PLKB, bidan desa, dan kader kesehatan serta tokoh masyarakat untuk mensosialisasikan alat kontrasepsi IUD.

\section{Daftar Pustaka}

Aspuah, Islaely Dan Proverawati. 2010. Panduan Memilih Kontrasepsi. Yogyakarta: Nuha Medika

Andriyani, Lusiana, Megasari. 2015. Metodologi Penelitian Kebidanan. Yogyakarta: CV Budi Utama.

Bakar, Abu dan Sukawati, 2014. Kesehatan Reproduksi dan Keluarga Berencana dalam tanya jawab. Jakarta: PT Raja grafindo Persada.

BKKBN Kalimantan Barat, 2016

Data Profil Rb Mariana Tahun 2017

Dewi Dan Wawan. 2010. Pengetahuan, Sikap, Dan Perilaku Manusia. Yogyakarta: Nuha Medika.

Hidayat, A. Aziz Alimul. 2014. Metode Penelitian Kebidanan Dan Teknik Analisis Data. Jakarta: Salemba Medika

Santosa, Heru. 2014. Analisis Faktor-Faktor Yang Memengaruhi Rendahnya Pemakaian Alat Kontrasepsi IUD (Intra 
Uterine Device) Oleh Ibu Pasangan Usia Subur.

https://jurnal.usu.ac.id/gkre/article/view/ 8439, di akses: tanggal 04 April 2018, 09.40 WIB

Irianto, Koes. 2014. Pelayanan Keluarga Berencana. Bandung: Alfabet.

Marmi. 2015. Kesehatan Reproduksi. Yogyakarta: Pustaka Pelajar.

2016. Buku Ajar Pelayanan KB. Yogyakarta: Pustaka Pelajar.

Mubarak, Igbal Wahid. 2015. Ilmu Kesehatan Masyarakat: Konsep Dan Aplikasi Dalam Kebidanan. Jakarta: Salemba Medika

Manueke. 2013. Faktor-faktor yang berhubungan dengan penggunaan Alat Kontrasepsi Dalam Rahim (AKDR). https://media.neliti.com/.../91578-IDfaktor-faktor-yang-berhubungandengan-pe.pdf, di akses: tanggal 04 April 2018, 10.00 WIB

Notoatmodjo, Soekidjo. 2010. Metodologi Penelitian Kesehatan. Jakarta: Rineka Cipta

Nurbaiti. 2013. Faktor-Faktor Yang Mempengaruhi Penggunaan Alat Kontrasepsi Intra Uterine Devise (IUD). Http://Simtakp.Uui.Ac.Id/, di akses: tanggal 5 April 2018, 07.54 WIB

Pinem, Saroha.2009. Kesehatan Reproduksi Dan Kontrasepsi. Jakarta: Trans Info Media
Profil Dinas Kesehatan Kabupaten Kubu Raya Tahun 2016.

Rado, Lantan. 2015. Gambaran Faktor-Faktor Yang Mempengaruhi Akseptor Tidak Memilih Kontrasepsi Jenis IUD Di Puskesmas Sungai Raya Dalam Kabupaten Kubu Raya. Akademi Kebidanan Panca Bhakti Pontianak (Tidak Dipublikasikan).

Kusumaningrum. 2013. Faktor-faktor yang berhubungan dengan Pasangan Usia Subur (PUS) tidak memilih metode kontrasepsi Intra Uterine Device (IUD). eprints.ums.ac.id/27175/22/02_NASKA H_PUBLIKASI.pdf, di akses tanggal 4 April 2018, 12.00 WIB

Setiyaningrum, Erna. 2015. Pelayanan Keluarga Berencana Dan Kesehatan Reproduksi. Jakarta: Cv. Trans Info Media

Suyanto Dan Susila. Metodologi Kesehatan Dan Kedokteran 2015. Metodologi Penelitian Cross Sectional Kedokteran \& Kesehatan. Klaten Selatan: Bossscript

Triwibowo Dan Pusphandani. 2015. Pengantar Dasar Ilmu Kesehatan Masyarakat. Yogyakarta: Nuha Medika

Uliyah, Mar'atul. 2010. Panduan Aman Dan Sehat Memilih Alat KB. Yogyakarta: PT Bintang Pustaka Abadi

Undang-Undang Republik Indonesia Nomor 20 Tahun 2003 Tentang Sistem Pendidikan Nasional 